\title{
PEMIKIRAN EKONOMI ISLAM UMER CHAPRA \\ (Studi Analisi Terhadap Sistem Ekonomi Kapitalisme, Sosialisme, dan Negara Sejahtera)
}

\author{
Dedi Mulyadi \\ Program Pasca Sarjana UIN Sunan Gunung Djati Bandung \\ Jl. A. H. Nasution Nomor 105 Bandung \\ Email: ghozinwirabumi1977@gmail.com
}

\begin{abstract}
Abstrak
Tulisan ini memaparkan pemikiran ekonomi Islam kontemporer melalui pendekatan mazhab mainstream, penganut mazhab ini salah satunya Umer Chapra. Pendekatan mazhab mainstream ini lebih dikenal dengan cara memadukan antara teori ekonomi konvensional dengan teori ekonomi Islam. Melalui penelitian dan analisisnya, Umer Chapra mengkritisi sistem-sistem ekonomi konvensional, seperti kapitalisme, sosialisme, dan negara sejahtera. Ia menyebutkan bahwa ketiga sistem tersebut belum mampu menyelesaikan persoalan-persoalan ekonomi dalam suatu negara. Ini terbukti dari ketiga sistem di atas masih mempunyai kelemahan-kelemahan, baik yang disadari maupun yang tidak disadari oleh pencetus sistem ekonomi tersebut. Akan tetapi, Umer Chapra tidak memusnahkan semua teori-teori yang pernah dibangun oleh para ekonom konvensional sebelumnya, namun Umer Chapra melalui pendekatannya ia memadukan antara teori ekonomi konvensional dengan teori ekonomi Islam, sehingga lahirlah yang disebut dengan mazhab mainstream.
\end{abstract}

\section{Kata Kunci:}

Kapitalisme, Negara Sejahtera, Sosialisme

\section{A. Pendahuluan}

Kegiatan ekonomi yang meliputi proses produksi, distribusi, dan konsumsi, ketiga proses tersebut merupakan elemen penting yang tidak bisa dipisahkan dalam hidup dan kehidupan manusia di dunia ini. Ketiga elemen tersebut dalam prosesnya terus berkembang seiring dengan perubahan zaman dan tuntutan manusia untuk memenuhi semua kebu- 
tuhan (need) dan keinginan (want) manusia, baik yang sifatnya primer, sekunder, maupun tersier. Oleh karena itu, pola pikir manusia hari ini telah teracuni oleh worldview Barat yang kapitalis, dan imperialis, sehingga hanya sedikit yang memahami konsep kehidupan islami dan worldview islami.

Untuk mengevaluasi dan mengkritik terhadap aliran-aliran ekonomi tersebut, seperti aliran ekonomi kapitalisme dan sosialisme yang dipandang tidak bisa menyelesaikan semua permasalahan ekonomi, maka muncullah aliran atau mazhab yang lahir dari pemikirpemikir ekonom Islam kontemporer seperti mazhab iqtishaduna, dan mainstream. Munculnya aliran atau mazhab ini dilatarbelakangi atas kegagalan dari aliran-aliran ekonomi yang sebelumnya yang dianggap tidak mampu dalam menjawab semua permasalahan ekonomi yang terus berkembang.

Pertama, mazhab iqtishaduna yang dipelopori oleh Baqir Al-Sadr dengan bukunya yang berjudul: "Iqtishaduna" (ekonomi kita). Mazhab ini berpendapat bahwa ilmu ekonomi (economics) tidak pernah bisa sejalan dengan Islam, karena keduanya berasal dari filosofi yang saling kontradiktif (anti-Islam dan Islam). ${ }^{1}$ Menurut Baqir Al-Sadr bahwa dalam mempelajari ilmu ekonomi harus dilihat dari dua aspek, yaitu aspek philosophy of economics atau normative economics dan aspek positive economics. Aspek positive economics, yaitu mempelajari teori konsumsi dan permintaan yang merupakan suatu fenomena umum dan dapat diterima oleh siapa pun tanpa dipengaruhi oleh ideologi. Adapun dari aspek phylosophy of economics yang merupakan hasil pemikiran manusia, akan dijumpai bahwa tiap kelompok manusia mempunyai ideologi, cara pandang dan kebiasaan yang tidak sama.

Kemudian, menurut Baqir Al-Sadr adanya kesenjangan secara terminologi antara pengertian ekonomi dalam perspektif ekonomi konvensional dengan pengertian ekonomi dalam perspektif Islam. Pandangan ini didasarkan pada pengertian dari ilmu ekonomi yang menyatakan bahwa masalah ekonomi timbul karena adanya masalah kelangkaan sumber daya ekonomi (scarcity) dibandingkan dengan kebutuhan manusia yang sifatnya tidak terbatas. Dalam hal ini Mazhab Baqir As-Sadr menolak pengertian tersebut, sebab dalam Islam telah ditegaskan bahwa Allah SWT telah menciptakan makhluk di dunia ini

${ }^{1}$ Adiwarman A. Karim, Ekonomi Mikro Islam (Jakarta: Rajawali Pers. 2012), hlm. 30. 
termasuk manusia dalam kecukupan sumber daya ekonomi sebagaimana ditegaskan melalui firman-Nya dalam Surat al-Furqan ayat $2 .{ }^{2}$

Selain itu, menurut mereka perbedaan filosofi akan berdampak pada perbedaan cara pandang keduanya dalam melihat masalah ekonomi. Menurut ilmu ekonomi, masalah ekonomi muncul karena adanya keinginan manusia yang tidak terbatas sementara sumber daya yang tersedia untuk memuaskan keinginan manusia tersebut jumlahnya terbatas. Mazhab Baqir menolak pernyataan ini, karena menurut mereka, Islam tidak mengenal adanya sumber daya yang terbatas. Dalil yang dipakai adalah Al-Qur'an surat Al-Qamar ayat 49. Namun Mazhab Baqir Al-Sadr berpendapat, bahwa masalah ekonomi muncul karena adanya distribusi yang tidak merata dan adil sebagai akibat sistem ekonomi yang membolehkan eksploitasi pihak yang kuat terhadap pihak yang lemah. Pihak yang kuat memiliki akses terhadap sumber daya sehingga menjadi sangat kaya, sementara yang lemah tidak memiliki akses terhadap sumber daya sehingga menjadi sangat miskin. Karena itu masalah ekonomi muncul bukan karena sumber daya yang terbatas, tetapi karena keserakahan manusia yang tidak terbatas. Oleh karena itu, menurut mereka, istilah ekonomi Islami adalah istilah yang bukan hanya tidak sesuai dan salah, tetapi juga menyesatkan dan kontradiktif, karena itu penggunaan istilah ekonomi Islami harus dihentikan. Sebagai gantinya, ditawarkan istilah baru yang berasal dari filosofi Islam, yaitu Iqtishad.

Kedua, mazhab mainstream yang berpandangan bahwa bahwa masalah ekonomi muncul karena sumber daya yang terbatas yang dihadapkan pada keinginan (want) manusia yang tidak terbatas dan tidak pernah merasa puas. ${ }^{3}$ Keterbatasan sumber daya memang ada dan diakui oleh Islam, ini terdapat dalam QS. al-Baqarah [2] ayat 155. Keterbatasan ini disebabkan karena kebutuhan dan keinginan manusia terus bertambah dan tidak pernah merasa puas, ini sesuai dengan firman Allah dalam QS. al-Takatsur [102] ayat 1-5.

Dengan demikian, pandangan mazhab ini tentang masalah ekonomi hampir tidak ada bedanya dengan pandangan ekonomi konvensional. Disebabkan karena kelangkaan sumber dayalah yang

2 Veithzal Rivai dan Andi Buchari, Islamic Economics: Ekonomi Syariah Bukan Opsi, Tetapi Solusi! (Jakarta: Bumi Aksara. 2009), hlm. 384-386.

3 M. Nur Rianto Al-Arif, Dasar-Dasar Ekonomi Islam (Solo: Era Adicitra Intermedia. 2011), hlm. 25 
menjadi penyebab munculnya masalah ekonomi. ${ }^{4}$ Perbedaan mazhab mainstream ini dengan ekonomi konvensional, yaitu dalam penyelesaian masalah ekonomi tersebut. Dalam ekonomi konvensional, pilihan dalam penentuan skala prioritas dilakukan berdasarkan selera pribadi masingmasing dan tidak peduli apakah itu bertentangan dengan norma serta nilai agama ataukah tidak. Dengan kata lain pilihan dilakukan berdasarkan tuntutan nafsu semata (homo economicus). Sedangkan dalam ekonomi Islam, penentuan pilihan tidak bisa seenaknya saja, sebab semua sendi kehidupan telah diatur oleh Quran dan Sunnah (homo islamicus). ${ }^{5}$

Tokoh-tokoh mazhab ini antara lain adalah Umer Chapra, Metwally, MA Mannan, MN Siddiqi, dan lain-lain. Mayoritas mereka adalah pakar ekonomi yang belajar serta mengajar di universitasuniversitas Barat, dan sebagian besar diantara mereka adalah ekonom Islamic Development Bank(IDB). Mazhab ini tidak pernah membuang sekaligus teori-teori ekonomi konvensional ke keranjang sampah. Salah seorang tokoh mazhab ini Umer Chapra mengatakan, bahwa usaha pengembangan ekonomi Islam bukan berarti memusnahkan semua hasil analisis yang baik dan berharga yang telah dicapai oleh para ekonom konvensional sebelumnya, akan tetapi ambil-lah sesuatu yang bermanfaat darinya dan kemudian buanglah sesuatu yang tidak bermanfaat darinya, sehingga terjadi suatu proses transformasi keilmuan yang diterangi dan dipandu oleh prinsip-prinsip syariah. ${ }^{6}$

Berdasarkan latar belakang di atas, penulis akan memaparkan salah satu pemikiran ekonom Islam kontemporer yaitu Umer Chapra, karena pemikiran-pemikirannya telah memberikan kontribusi berarti dalam proses islamisasi ilmu ekonomi. Ia merupakan salah seorang ekonom muslim kontemporer yang menggemakan mazhab atau aliran mainstream.

\section{B. Biografi Umer Chapra}

Umer Chapra dilahirkan pada tanggal 1 januari 1933 yang bertempat di Pakistan. Ayahnya bernama Abdul Karim Chapra. Ia terlahir dengan penuh keberuntungan karena keluarganya adalah keluarga yang taat beragama, sehingga dalam dirinya tertanam dan tumbuh menjadi orang yang berkepribadian baik.

\footnotetext{
${ }^{4}$ Adiwarman A. Karim, Ekonomi Mikro Islami. hlm. 31-32

${ }^{5}$ M. Nur Rianto Al-Arif, Dasar-Dasar Ekonomi Islam. hlm. 26.

${ }^{6}$ Ibid., hlm. 26.
} 
Umer Chapra meneruskan pendidikan strata satu dan magister di Karachi, Pakistan. Kemudian meraih gelar Ph.D., pada bidang ekonomi pada tahun 1961 dengan predikat cumlaude di Universitas Minnesota, Minneapolis, Amerika Serikat. Kemudian dia kembali ke negara asalnya dan bergabung dengan Central Institute of Islamic Research di tahun yang sama. Selama 2 tahun berada di dalam lembaga tersebut Chapra aktif melakukan penelitian kajian yang sistematis terhadap gagasangagasan dan prinsip-prinsip tradisi islam untuk mewujudkan sistem ekonomi yang sehat. Hasil kajian itu, dia tuliskan dan dibukukan dengan judul The Economic System ofIslam: A Discussion of Its Goals and Nature, diterbitkan di London tahun 1970. Selain itu, dia juga menjabat sebagai ekonom senior dan Associate Editor pada Pakistan Development Review di Pakistan Institute of Economic Development.

Pada tahun 1964, Chapra kembali ke Amerika dan mengajar di beberapa sekolah tinggi ternama. Di antaranya adalah Harvard Law School, Universities of Wiscousin, United States, Universitas Autonoma, Madrid, Universitas Loughborough, U.K, Oxford Center for Islamic Studies, London School of Economic, Universitas Malaga, Spanyol, dan beberapa Universitas di berbagai negara lainnya. Kemudian dia bergabung dengan Saudi Arabian Monetary Agency (SAMA), Riyadh, dan menjabat sebagai penasihat ekonomi hingga pensiun pada tahun 1999. Selain itu dia juga menjabat sebagai penasehat riset di Islamic Research and Training Institute (IRTI) di Islamic Development Bank (IDB), Jeddah.

Umer Chapra juga bertindak sebagai komisi teknis dalam Islamic Financial Services Board (IFSB) dan menentukan rancangan standar industri keuangan Islam tahun 2002 sampai dengan tahun 2005. Atas kiprah dan jasanya dalam dunia ekonomi Islam, dia mendapatkan penghargaan dari the Islamic Development Bank untuk bidang Ekonomi Islam, dan penghargaan dari King Faisal untuk bidang studi Islam, yang keduanya diraih pada tahun 1990. Selain itu, dia juga mendapatkan penghargaan yang dianugrahkan langsung oleh Presiden Pakistan, berupa medali emas dari IOP (Islamic Overseas of Pakistanis) untuk jasanya terhadap Islam dan Ekonomi Islam, pada konferensi pertama IOP di Islamabad.7

7 Euis Amalia, Sejarah Pemikiran Ekonomi Islam; Dari Masa Klasik Hingga Kontemporer (Depok: Gramata Publishing. 2005), hlm. 297-298. Lihat juga M. Umer Chapra dan Habib Ahmed, Corporate Governance, Edisi terjemahan: Lembaga Keuangan Syariah. Penerjemah: Ikhwan Abidin Basri, (Jakarta Timur: PT. Bumi Aksara. 2008), hlm. 221. 


\section{Sistem-sistem yang Gagal}

\section{Kapitalisme}

Kapitalisme merupakan sistem ekonomi yang secara jelas ditandai dengan berkuasanya "kapital", sehingga tidak adanya perencanaan ekonomi sentral. Kapitalisme menjadikan harga pasar sebagai dasar keputusan dan perhitungan unit yang diproduksi. Sistem ekonomi pada umumnya tidak ditentukan oleh pemerintah, tetapi ditentukan oleh kekuatan pasar dan kekuasaan pengusaha dalam memperoleh keuntungan. Sistem ekonomi kapitalisme lahir akibat adanya persaingan, kemudian seleksi alam berjalan sehingga terciptalah tingkatan atau kelas seseorang dalam menduduki posisinya, artinya bahwa kelas kapitallah yang akan menduduki kelas paling atas dan mempunyai kekuasaan dalam mengendalikan ekonomi. ${ }^{8}$

Menurut Umer Chapra, konsep dan strategi yang tidak dicapai baik yang disadari maupun yang tidak disadari dalam sistem ekonomi kapitalisme, di antaranya sebagai berikut:9 Pertama, kepercayaan hukum-hukum ekonomi yang didasarkan pada pandangan mekanis terhadap jagat raya, bahwa pengetahuan dan sains-sains sosial tidak berbeda dari sains-sains fisika dan perilaku manusia. Smith meminjam pandangan fisika Newton, bahwa kehidupan sosial dan ekonomi, sama seperti dunia fisika, yaitu indah, teratur, dan harmoni. Semenjak itu para ekonomi telah dipengaruhi oleh bayangan keagungan hukum-hukum fisika dan terkadang mereka berharap akan melahirkan hukum-hukum gerakan ekonomi sekokoh hukum-hukum Newton.

Kedua, yaitu "manusia ekonomi rasional" yang berfungsi sebagai titik sentral ilmu ekonomi modern. Kepentingan diri sendiri merupakan satu-satunya muara bagi seluruh gerakannya, semua tindakannya sesuai dengan apa yang disebut oleh Javons, yaitu sebagai mesin nilai guna dan kepentingan diri. Kemudian menurut Friedman, yaitu seberapa besar tingkat keuntungannya dalam memenuhi tanggung jawab sosialnya. Pernyataan Javons dan Friedman diperkuat oleh Edgeworth dengan bangga menyatakan, bahwa prinsip pertama ilmu ekonomi adalah setiap agen (pelaku) hanya dimotori oleh self-interest. Kemudian kontribusi besar Adam Smith bagi pemikiran ekonomi adalah kesakralan yang ia

${ }^{8}$ Euis Amalia, Sejarah Pemikiran Ekonomi Islam. hlm. 298. Lihat juga M. Abdul Manan, Teori dan Praktik Ekonomi Islam (Yogyakarta: PT. Dana Bhaktif. 1997), hlm. 315.

${ }_{9}^{9} \mathrm{M}$. Umer Chapra, Islam and The Economic Chalenge, Edisi terjemahan: Islam dan Tantangan Ekonomi. Penerjemah: Ikhwan Abidin Basri, (Jakarta: Gema Insani. 2000), hlm. 28-31. 
gunakan kepada self-interest, sehingga memalingkan matanya dari perhatian-perhatian ke arah moral dan tanggung jawab sosial individu terhadap konsekuensi-konsekuensi yang tidak diinginkan atau hasil sosial akhir dari aksi-aksinya.

Ketiga, positivisme. Konsep ini merupakan payung kesakralan yang diberikan kepada "ilmu ekonomi positif" yang secara harfiah dianggap sebagai "kebebasan dari posisi etika tertentu atau penilai normatif". Optimalitas Pareto, diidentifikasikan dengan "efisiensi ekonomi" dan telah menjadi anak favorit ilmu ekonomi kesejahteraan (welfare economics). Misalnya, jika ada sejuta orang yang merasa dirinya lebih baik (sejahtera), tetapi ada satu orang yang merasa kurang sejahtera sebagai akibat dari implementasi suatu kebijakan misalnya, maka para ekonom akan maju ke depan untuk menghentikan penilaian mengenai baik tidaknya implementasi kebijakan tersebut. Hal ini menyebabkan proses pembuatan kebijakan nyaris lumpuh, terutama dalam masyarakat pluralis yang masing-masing kelompok mencoba memenuhi kepentingannya sendiri.

Keempat, Hukum Say. Ini merupakan turunan dari pentingnya penerapan hukum-hukum fisika Newton dalam ilmu ekonomi. Hukum Say ini menyatakan, seperti halnya alam semesta, ekonomi akan berjalan mulus jika dibiarkan bergerak sendiri. Produksi akan menciptakan permintaannya sendiri, sehingga tidak akan ada yang disebut over produksi atau pengangguran. Pemerintah tidak boleh campur tangan, karena kekuatan pasar-lah yang akan menciptakan keteraturan, keharmonisan, efisiensi, dan pemerataan.

\section{Sosialisme}

Strategi Marxis untuk menghapuskan kesulitan dan penderitaan golongan miskin (buruh) yang menjadi karakteristik kapitalisme yaitu dengan cara membatasi kepemilikan swasta yang diduduki oleh kaum borjuis yang memiliki sarana produksi. Selain itu, yang menjadi poin penting dalam menumbuhkembangkan sosialisme ini yaitu, masyarakat buruh dibekali keahlian, kemampuan mental, pendidikan, kreativitas, ambisi dan semangat kerja keras. Kemudian strategi Marxis pada fase pascarevolusi, yaitu setelah tercapainya kepemilikan negara atas semua semua sarana produksi dan perencanaan terpusat, berharap dapat melakukan efisiensi dan pemerataan dalam alokasi sumber daya sesuai dengan kemampuan dan keahliannya. Akan tetapi, harapan ini terbukti 
tidak benar, karena adanya kelemahan-kelemahan serius dalam penalaran Marxis tersebut.

Seperti halnya sistem ekonomi kapitalisme, sosialisme juga yang merupakan asumsi-asumsi strategi Marxis memiliki kelemahankelemahan, meskipun sebagai orang tidak menyadari hal ini. Kelemahan tersebut di antaranya sebagai berikut: ${ }^{10}$ Pertama, Ketidakpercayaan dan Kepercayaan. Analisis Marxis mengandung pengertian adanya suatu ketidakpercayaan total terhadap kemampuan manusia untuk mengelola barang-barang swasta dalam batasan-batasan kemaslahatan manusia. Diasumsikan secara tersirat bahwa setelah diberlakukan sosialisme, manusia yang sama dalam kapasitasnya sebagai konsumen, pekerja, manajer perusahaan, dan pegawai pemerintah, akan selalu dimotivasi untuk melakukan yang terbaik bagi kepentingan sosial, tanpa peduli kepada kepentingannya sendiri. Ini mengandung implikasi sebagai berikut:

1) Para pekerja akan bekerja secara efisien, jujur, dan tidak memedulikan kepentingannya, meskipun tidak mendapatkan upah yang setimpal;

2) Para manajer perusahaan akan beroperasi secara efisien tanpa dapat melayani kepentingan dirinya sendiri, tanpa merasa dipaksa untuk bersaing, dan tanpa memiliki kemampuan untuk membuat keputusan sendiri dalam membeli dan menjual faktor-faktor produksi atau output-nya; dan

3) Para pegawai pemerintah tidak akan mengambil keuntungan berlebihan dalam pembuatan berbagai keputusan dan dalam kedudukannya sebagai penguasa eksekutif.

Kedua, Keharmonisan Kepentingan. Diasumsikan bahwa mesin pemerintah akan dijalankan oleh sekelompok orang yang kepentingannya seirama dengan kepentingan masyarakat. Asumsi ini dikatakan tidak benar, karena sebuah masyarakat totalitarian sekalipun, tidak akan dapat melepaskan diri dari pluralitas kepentingan dan hak-hak istimewa yang muncul dari faktor-faktor seperti posisi dalam struktur kekuasaan, persaingan, dan asal daerah.

Ketiga, Ketesediaan Informasi. Diasumsikan bahwa mesin perencanaan pusat memiliki informasi mengenai preferensi konsumen, ongkos produksi, dan harga-harga yang sangat diperlukan, untuk mem- 
buat berbagai keputusan. Ketersediaan informasi tidak mungkin dimiliki tanpa adanya interaksi bebas antara permintaan dan penawaran di dalam pasar. Oleh karena itu, argumen Hayek menyatakan bahwa solusi sosialis terhadap masalah alokasi sumber daya sama sekali tidak praktis, karena pengetahuan atau informasi sempurna mengenai datadata yang relevan tidak tersedia oleh pihak otoritas.

Keempat, Manfaat Subsidi. Dengan adanya subsidi-subsidi besar besar yang terdapat dalam sistem penentuan harga di (bekas) Uni Soviet, akan bermanfaat bagi orang-orang miskin. Strategi ini terbukti salah, karena manfaat subsidi hanya akan banyak dinikmati oleh kelompok-kelompok kaya saja, sedangkan kelompok miskin tidak akan merasakan manfaat subsidi, sebab daya beli mereka terbatas. Keuntungan-keuntungan subsidi yang terus mengalir ke kelompok kaya berarti telah menghukum para petani yang menjual hasil-hasil pertaniannya dengan harga rendah, sehingga insentifuntuk bekerja secara efisien dalam meningkatkan produktivitasnya menjadi mati.

Kelima, Efisiensi Pertanian. Diasumsi kan bahwa pertanianpertanian besar monopolistik dan BUMN-BUMN akan beroperasi secara efisien sekalipun mengalami skala disekonomi, kurangnya kompetisi, dan ketiadaan-ketiadaan sinyal pasar. Asumsi ini terbukti salah. Pertanian-pertanian besar pada umumnya menanam bermacam-macam jenis tanaman, juga berbagai jenis peternakan dan memiliki sejumlah besar buruh yang hidup berpencar di beberapa pedesaan dan pedukuhan, sehingga akan menyulitkan pekerjaan supervisi. Seorang petani kecil atau penggarap dapat melakukan pekerjaan ini dengan baik dan efisien karena mereka menginginkan hasil pertaniannya. Akan tetapi, jika ada banyak variasi pekerjaan pada suatu pertanian kolektif, maka tidak dapat dilakukan dengan baik.

\section{Negara Sejahtera}

Filsafat negara sejahtera mengakui full employment11 dan distribusi pendapatan dan kekayaan yang adil sebagai bagian dari tujuan pokok negara. Negara sejahtera depresi besar dan kemudian setelah perang dunia kedua, tujuan jangka pendeknya yaitu untuk menghapus-

11 Full employment adalah kondisi perekonomian nasional, dimana semua atau hampir semua orang mau dan mampu bekerja dengan upah yang berlaku dan kondisi kerja yang mampu melakukannya. Ini didefinisikan baik sebagai pengangguran $0 \%$, secara harfiah, tidak ada pengangguran. 
kan ekses-ekses kapitalisme yang paling mencolok dan mengurangi daya tarik sosialisme. Falsafah yang mendasarinya menunjukkan suatu gerakan menjauhi prinsip-prinsip Darwanisme-sosial ${ }^{12}$ dari kapitalisme dan menuju kepercayaan bahwa kesejahteraan individu merupakan sasaran yang teramat penting, yang realisasisanya diserahkan kepada operasi kekuatan-kekuatan pasar. ${ }^{13}$

Strategi dan kelemahan sistem negara sejahtera menurut penelitian dan analisa Umer Chapra dapat dilihat dari aspek-aspek di bawah ini:14 Pertama, aspek regulasi. Tidak ada keraguan bahwa regulasi perusahaan-perusahaan swasta penting bagi terjaminnya kompetisi, terpeliharanya tatanan dan standar, dan perlindungan hak-hak orang lain. Tetapi, regulasi menuntut kriteria yang disepakati oleh nilai-nilai kolektif, jika kriteria dan nilai itu tersedia atau secara universal tidak diakui, maka dalam masyarakat pluralis yang setiap orang mengedepankan kepentingan dirinya sendiri, negara menjadi sebuah papan netral bagi semua kelompok yang berkepentingan, dan segala aktivitasnya hanya akan menjadi sasaran tawar-menawar dan perlombaan politik. Sehingga regulasi apapun yang ditegakkan di bawah tekanan angin politik, niscaya akan cenderung melempem atau dihapuskan oleh perubahan politik.

Kedua, Nasionalisasi. ${ }^{15}$ Gerakan nasionalisasi industri-industri utama juga telah kehilangan momentumnya, ini disebabkan bukan saja karena kemunduran umum kinerja industri-industri yang dinasionalisasi, tetapi juga karena besarnya subsidi yang diserap oleh industriindustri ini untuk mempertahankan kelangsungan hidupnya, dan kadang-kadang karena keterbatasan politik yang menahannya untuk mematok harga berdasarkan interaksi pasar.

Ketiga, Gerakan Serikat Buruh. Ini dianggap sebagai panasea (obat mujarab) untuk meningkatkan pendapatan kaum buruh, memperbaiki kondisi kerja, dan menyediakan mereka program keamanan ekonomi, kini telah kehilangan momentum sebagai akibat dari adanya inflasi dan pengangguran yang tinggi. Upah yang terus merosot dipandang sebagai penyebab inflasi karena desakan ongkos, kekakuan upah umumnya

12 Kesakralan yang ia gunakan kepada self-interest, sehingga memalingkan matanya dari perhatian-perhatian ke arah moral dan tanggung jawab sosial.

${ }^{13}$ Ibid. hlm. 113.

${ }^{14}$ Ibid. hlm. 115-130.

15 Nasionalisasi adalah pengambilalihan kepemilikan oleh pemerintah nasional atas bisnis atau industri swasta (KBBI online). 
dipandang sebagai penyebab utama pengangguran. Sebagai konsekuensinya, gerakan antiserikat buruh meningkat di banyak negara industri dan serikat buruh terus mengalami kemunduran.

Keempat, Kebijakan Fiskal. Ini merupakan alat utama bagi negara kesejahteraan. Ia meliputi penggunaan belanja pemerintah, perpajakan progresif, dan pinjaman untuk mencapai sasaran-sasaran yang diinginkan. Berdasarkan analisis Umer Chapra, bahwa kebijakan fiskal dalam sistem negara sejahtera memiliki kelemahan yang disebabkan sebagai berikut: (1) tingkat pajak yang tinggi karena beban pengeluaran negara sejahtera lebih besar, sehingga ada perlawanan terhadap perpajakan; (2) subsidi yang tidak merata, ini disebabkan karena perlakukan yang sama kepada golongan kaya dan miskin untuk memperoleh manfaat dari hasil subsidi tersebut; dan (3) ketidakmerataan pendapatan dan kekayaan tetap meningkat.

Kelima, Pertumbuhan yang Tinggi. Dua dasawarsa dari pengalaman pertumbuhan yang tinggi dan peningkatan kekayaan yang kontinue telah terbukti gagal menghapuskan kemiskinan, memenuhi kebutuhan-kebutuhan pokok, dan mengurangi kesenjangan.

Keenam, Kesempatan Kerja Penuh. Pengangguran masih menjadi persoalan yang belum dapat dipecahkan di negara-negara industri dalam sistem negara sejahtera. Hal yang lebih mencemaskan lagi adalah makin tingginya jumlah pemuda yang menganggur, sehingga menurunkan gengsi mereka, menghambat kepercayaan masa depannya, meningkatkan permusuhan terhadap masyarakat, dan merusak kapasitas personal mereka serta kontribusi sosialnya.

\section{Pandangan Dunia Islam dan Strateginya}

Islam merupakan agama yang universal, sederhana, mudah dimengerti dan dinalar. Ia didasarkan pada tiga prinsip fundamental, yaitu: 1) tauhid "keesaan"; 2) khilafah "perwakilan"; dan 3) 'adalah (keadilan). 16

\section{Tauhid (Keesaan Tuhan)}

Segala sesuatu yang lain secara logika bermuara dari prinsip tauhid, karena tauhid mengandung arti bahwa alam semesta ini didesain dan diciptakan secara sadar oleh Tuhan Yang Maha Kuasa, dan tidak menciptakan sesuatunya tidak secara kebetulan atau aksiden. ${ }^{17}$

\footnotetext{
${ }^{16}$ Ibid. hlm. 204-215.

${ }^{17}$ Q.S. ali-Imran ayat 191.; Q.S. Shad ayat 27.; dan Q.S. al-Mu'minun ayat 15.
} 
Segala sesuatu yang diciptakan-Nya memiliki tujuan yang akan memberikan arti yang signifikan bagi eksistensi jagat raya ini, di mana manusia merupakan salah satu bagiannya. Tuhan aktif terlibat dalam segala urusannya ${ }^{18}$ dan selalu waspada dan melihat kejadian yang paling kecil sekalipun. ${ }^{19}$

\section{Khilafah (Perwakilan)}

Manusia adalah khalifah-Nya atau wakil-Nya, ${ }^{20}$ ia telah dibekali dengan semua karakteristik mental dan spiritual serta materil untuk memungkinkannya hidup dan mengemban misinya secara efektif. Dalam kerangka kekhalifahannya, ia bebas dan mampu berpikir dan menalar untuk memilih mana yang baik dan mana yang buruk, jujur atau tidak jujur, dan mengubah kondisi kehidupan, masyarakat, dan perjalanan sejarahnya, jika ia berkehendak demikian. Secara fitrah, ia baik dan mulia ${ }^{21}$ serta mampu melindungi kebaikan dan kemuliaannya.

Konsep khilafah memiliki sejumlah implikasi, yaitu sebagai berikut:

\section{1) Persaudaraan Universal}

Dalam kerangka konsep persaudaraan ini, sikap yang benar terhadap sesama manusia bukanlah "kekuatan itu yang benar", berjuang untuk "kepentingan diri sendiri", atau "si kuat yang menang", tetapi pengorbanan dan kerjasama yang saling menguntungkan untuk memenuhi kebutuhan pokok semua orang, mengembangkan potensi seluruh kemanusiaan dan memperkaya kehidupan manusia.

2) Sumber Daya Alam adalah Amanat

Pengertian amanat di sini bukan berarti "meniadakan kepemilikan privat terhadap kekayaan", tetapi memberikan sejumlah implikasi penting yang menciptakan perbedaan revolusioner dalam konsep kepemilikan sumber daya dalam Islam dan sistem ekonomi lainnya.

3) Gaya Hidup Sederhana

Satu-satunya gaya hidup yang sesuai dengan kedudukan khalifah adalah gaya hidup sederhana. Ia tidak boleh merefleksikan sikap arogansi, kemegahan, kecongkakan, dan kerendahan moral.

4) Kebebasan Manusia

${ }^{18}$ Q.S. Yunus ayat 3. dan Q.S. al-Sajdah ayat 5.

${ }^{19}$ Q.S. Lukman ayat 16. dan Q.S. al-Mulk ayat 14.

20 Q.S. al-Baqarah ayat 30.; Q.S. al-An'am ayat 165.; Q.S. Fathir ayat 39.; Q.S. Shad ayat 28.; dan Q.S. al-Hadid ayat 7.

${ }^{21}$ Q.S. al-Hijr ayat 29.; Q.S. al-Rum ayat 30.; dan Q.S. al-Tin ayat 4. 
Kebasan di sini bukan berarti bebas berbuat sekehendak, karena manusia dibatasi oleh syariat yang bertujuan memelihara kemaslahatan semua orang dengan menegakkan disiplin pada diri mereka.

\section{3. 'Adalah (Keadilan)}

Persaudaraan yang merupakan bagian integral dari konsep tauhid dan khilafah akan tetap menjadi kosong yang tidak memiliki substansi, jika tidak dibarengi dengan keadilan sosio-ekonomi. Komitmen Islam yang begitu intens kepada persaudaraan dan keadilan menuntut semua sumber daya di tangan manusia sebagai suatu titipan sakral dari Allah dan harus dimanfaatkan, seperti: 1) pemenuhan kebutuhan pokok; 2) sumber-sumber pendapatan yang terhormat; 3) distribusi pendapatan dan kekayaan yang merata; dan 4) pertumbuhan dan stabilitas.

Tiga prinsip di atas, merupakan dasar yang fundamental sebagai pijakan dalam peningkatan stabilitas perekonomian umat. Selain dari ketiga prinsip di atas, Umer Chapra memberikan strategi-strategi yang meliputi reorganisasi keseluruhan sistem ekonomi dengan empat elemen yang saling memperkuat, yaitu: 1) sebuah mekanisme filter yang secara sosial disepakati; 2) sebuah sistem motivasi yang mendorong individu untuk melakukan yang terbaik untuk dirinya dan masyarakatnya; 3) restrukturisasi perekonomian secara keseluruhan dengan tujuan mewujudkan maqasid meskipun menghadapi kelangkaan sumber daya; dan 4) sebuah peran pemerintah yang positif dan kuat.

\section{E. Penutup}

Berdasarkan pemaparan di atas, bahwa ketiga sistem ekonomi yang dibangun oleh Adam Smith, Marx, dan Keynes belum mampu menyelesaikan semua permasalahan-permasalahan ekonomi dalam suatu negara. Ini terbukti dengan hasil penelitian dan analisisnya yang dilakukan oleh Umer Chapra terhadap ketiga sistem ekonomi tersebut masih mempunyai banyak kelemahan-kelemahan. Akan tetapi, Umer Chapra tidak memusnahkan semua teori-teori yang pernah dibangun oleh para ekonom konvensional sebelumnya, namun Umer Chapra melalui pendekatannya ia memadukan antara teori ekonomi konvensional dengan teori ekonomi Islam, sehingga lahir-lah yang disebut dengan mazhab mainstream. 


\section{DAFTAR PUSTAKA}

Al-Arif, M. Nur Rianto. 2011. Dasar-Dasar Ekonomi Islam. Solo: Era Adicitra Intermedia.

Amalia, Euis. 2005. Sejarah Pemikiran Ekonomi Islam; Dari Masa Klasik Hingga Kontemporer Depok: Gramata Publishing.

Chapra, M. Umer dan Habib Ahmed. 2008. Corporate Governance, Edisi terjemahan: Lembaga Keuangan Syariah. Penerjemah: Ikhwan Abidin Basri, M.A, M.Sc. Jakarta Timur: PT. Bumi Aksara.

Chapra, M. Umer. 2000. Islam and The Economic Chalenge, Edisi terjemahan: Islam dan Tantangan Ekonomi. Penerjemah: Ikhwan Abidin Basri, M.A, M.Sc. Jakarta: Gema Insani.

Karim, Adiwarman A. 2012. Ekonomi Mikro Islam. Jakarta: Rajawali Pers. 2012.

Rivai, Veithzal dan Andi Buchari. 2009. Islamic Economics: Ekonomi Syariah Bukan Opsi, Tetapi Solusi!. Jakarta: Bumi Aksara. 